\title{
FACTORS AFFECTING TOURISTS SATISFACTION IN CANDIREJO TOURISM VILLAGE, INDONESIA
}

\author{
Janne Hillary \\ Faculty of Animal and Agricultural Sciences, Diponegoro University, Indonesia \\ hillaryjanne@gmail.com
}

\begin{abstract}
Candirejo Village is a tourism village which focuses on the natural nuance of the village. The current challenge faced by Candirejo Village is how to significantly increase the number of tourists per year. In dealing with this challenge, the management should manage tourists satisfaction. The factors that need to be paid attention to the tourists' satisfaction are the attraction, facility, service, accessibility, and price. This study aims to examine and analyze the effect of attraction, facility, service, accessibility, and price on the tourist's satisfaction of Candirejo Village. The analysis results show that all of the independent variables jointly affect the tourist's satisfaction in Candirejo Village. Despite that, the price was the only factor individually affecting the tourist's satisfaction in Candirejo Village. Therefore, attraction, facility, service, accessibility, and price are multi-factors. Optimal synergized of these factors can increase the tourist's satisfaction in Candirejo Village.
\end{abstract}

Keywords: Candirejo Village; Tourists Satisfaction; Nature-based Tourism

\section{INTRODUCTION}

Indonesia has a significant opportunity to develop the tourism industry because the country is rich in potential resources that can generate income and is able to make development capital at the local, regional and national levels (Kementerian Perdagangan Republik Indonesia, 2011). Tourism village is one of the sub-sectors of tourism that takes benefits from the natural nuances of villages in Indonesia (Permanasari, 2011).

A tourism village is not just a particular tourist site in a village, but a rural area that presents a whole ambience imaging the unique and attractive rural authenticity, and has the potential to develop its tourism component (Kurniasih et al., 2017; Sulistyadi et al., 2019). It will be a complete integration if tourists can stay to taste local foods and many types of cultural attractions (Kurniasih et al., 2017). A tourism village has a unique attraction, such as the physical uniqueness of the rural natural environment, as well as the social and cultural life of its people, which is naturally and attractively packaged. Its rural attraction is expected can attract tourists to the village (Damanik et al., 2018).

There has been a change in travel trends where travel motivation has changed. Tourists want a more meaningful trip to improve their quality of life, by doing an unique and special interest travel, like nature and culture trip. That change makes the tourism village spread widely across Indonesia, including in the province of Central Java (Kurniasih et al., 2017; Santosa \& Saputra, 2018; Sulistyadi et al., 
2019). Nowadays, there are 125 tourism villages in Central Java which are spread over several districts and cities. One of the tourism villages that get the Central Java government's attention is Candirejo Village (Santosa \& Saputra, 2018).

Candirejo Village is a village located near to Borobudur Temple world heritage site, Magelang Regency. Candirejo Village is commonly known as the Ecotourism Village. The reliable tour package focuses on ecotourism because Candirejo Village has attractive natural potential to visit and most villagers work as palawija (secondary crops) farmers such as cassava, beans, red chilli, corn, etc. (Permanasari, 2011). Developing from Candirejo Village to Candirejo Tourism Village is expected to increase farmers's income without disrupting the agriculture (Kurniasih et al., 2017).

The fact, the community still mostly earns income from agriculture activities. It is only a small percentage of them who work in tourism (Permanasari, 2011). The program of Candirejo Village as tourism village is not implemented optimally and the average tourists are only a few. In 2017, the average number of tourists to Candirejo Village was only 18 people per day (Candirejo Tourism Village Cooperative, 2018; Permanasari, 2011).

The location of Candirejo Village which is only about $3 \mathrm{~km}$ from the popular site, Borobudur, should be an opportunity to get more tourists, along with increasing number of tourists to Borobudur. Thus, Candirejo Village faces the current challenge that how to significantly increase the number of tourists per year. To deal with this challenge, the management should manage the tourist's satisfaction.

Tourists' satisfaction is defined as the overall attitude shown by tourists after they acquire and use tourism services or products. If a tourism service or product's performance can not fulfil their expectation, dissatisfaction will appear (Hayati \& Novitasari, 2017). In simple words, when experiences of a tourist result in the feeling of gratification, the satisfaction is created. It is referred to justification of the tourists on the delivered services after the travel based on their real experiences (Sadeh et al., 2012).

The quality of a tourism business that is provided in a tourist destination has major influence in overall tourist satisfaction (Akama \& Kieti, 2003). The dimensions of the tourism business quality have five dimensions of attraction, facilities, service, accessibilities of destination, and price (expenses incurred by tourists). Those dimensions are important factors and ultimately determine success in the tourism business (Hayati \& Novitasari, 2017).

Attraction becomes the most important component of the tourism. It is usually a tourist motivation to travel. Everything that has the uniqueness, beauty and value in the form of diversity of natural wealth, culture and man-made products becomes a target of tourist visits. Other important attribute in tourism is the facility. It includes public facilities in a tourist destination and special facilities tailored to meet tourists' needs (Hayati \& Novitasari, 2017).

Customer satisfaction in the tourism industry is also affected by a level of attitude and the hospitality services presented by local tourism workers (Yusendra \& Paramitasari, 2018). Local community support for tourism and hospitable tourism employee affect tourists' impressions. It is closely linked to word-of-mouth recommendations, one of the most valuable travel information sources (Wilson et al., 2001). Facilities and services are supporting factors of tourists' satisfaction 
because if they are not qualified, the volume of tourists will be decreased (Hayati \& Novitasari, 2017).

Accessibility of destinations is also an important factor since it affects the cost of vacationing, the speed, and convenience of a traveller to reach a destination. Bad effect on tourists' satisfaction may be caused by a lack of good access to travel. (Hayati \& Novitasari, 2017). Overall tourist satisfaction is affected not only by the quality of the tourism business that tourists receive, but also by price and perceived value. Price reflects the value that tourists receive. Tourists are looking for value for money, which means there is a good combination of cost, quality and sustainability to meet tourists requirements (Akama \& Kieti, 2003). Informing tourists about reasons for expensive goods and services could improve destination image (Shahrivar, 2012).

With high satisfaction, tourists who have visited will be interested in coming back and recommending Candirejo Village as a tourist destination to their close relatives. It will be the cheapest and most effective form of marketing and promotion. The impact is the number of tourists will tend to increase (Akama \& Kieti, 2003; Stevianus, 2014). The increase in tourist numbers is expected to contribute economically, both directly and indirectly to the local community, as well as to increase their social lives (Handriana, 2015; Permanasari, 2011). Economic improvement can be seen from increasing income, increasing employment opportunities, increasing physical assets, and increasing land values (Gokovali \& Bahar, 2006). If tourist satisfaction will always be kept, the destination will reach longterm economic success (Akama \& Kieti, 2003).

Because of the importance of tourist satisfaction, the study on factors that affect tourist satisfaction in Candirejo Tourism Village is needed. This study aims to examine and analyze the impact of attractions, facilities, services, accessibility, and prices on tourist satisfaction of Candirejo Village.The study is expected to be a suggestion of the right strategy in increasing tourists' satisfaction of Candirejo Village for the government and society. The present study can also be an additional contribution to the research literature about rural tourism.

\section{METHODOLOGY}

The study was conducted in Candirejo Village, Magelang Regency, by considering the tourism village as a rural tourism development trend in Magelang. The study was conducted at the end of November 2019. This study used primary and secondary data. The instrument used to collect and record primary data for this study was survey questionnaires.

There were two types of questionnaires: close-ended questionnaires and open-ended questionnaires. To get information about tourist perception and satisfaction, the author used a close-end questionnaire with some variables such as the tourist's satisfaction (y), attraction (x1), facility (x2), service (x3), accessibility $(\mathrm{x} 4)$, and price $(\mathrm{x} 5)$. Factors affecting tourist satisfaction and the indicators can be seen in Table 1. Those indicators form the basis of the questionnaire questions. 
Table 1. Factors affecting tourist satisfaction and indicators.

\begin{tabular}{|c|c|}
\hline Factor & $\begin{array}{l}\text { Indicator of Satisfaction (Akama \& Kieti, 2003; Hayati \& } \\
\text { Novitasari, 2017; Kerdpitak \& Heuer, 2016; Suanmali, 2014; } \\
\text { Yusendra \& Paramitasari, 2018) }\end{array}$ \\
\hline attraction (x1) & $\begin{array}{lll}- & \text { Visual attractive and appealing of natural attractions } \\
- & \text { Appealing and good condition of man-made attractions } \\
- & \text { Interesting outdoor activities } & \\
- & \text { Unique } & \text { cultural }\end{array}$ \\
\hline facility (x2) & $\begin{array}{ll}\text { - } & \text { Information centre with relevant information about the site } \\
- & \text { Comfortable seating } \\
- & \text { Availability of clean public toilets } \\
- & \text { Availability of clean prayer room } \\
- & \text { Availability of large parking area } \\
- & \text { Availability of accommodation } \\
- & \text { Existence of alternative souvenir shops } \\
& \text { Restaurant or food court that serves clean, delicious and } \\
\text { - } & \text { good quality foods } \\
\text { Trash cans allocated everywhere }\end{array}$ \\
\hline service (x3) & $\begin{array}{ll}- & \text { Competent staff } \\
\text { - } & \text { Staff who are willing to help } \\
- & \text { Friendly staff } \\
\text { - } & \text { Warm and welcoming atmosphere } \\
- & \text { Expert tour guide } \\
- & \text { Give adequate safety facilities } \\
- & \text { Clean and comfortable facilities }\end{array}$ \\
\hline $\begin{array}{l}\text { accessibility } \\
(\mathrm{x} 4)\end{array}$ & $\begin{array}{ll}\text { - } & \text { Convenience to travel } \\
\text { - } & \text { Existence of a road guide } \\
\text { - } & \text { Accessible roads to reach the site } \\
\text { - } & \text { Availability of public transport to reach the site } \\
& \text { The road can accommodate large vehicles }\end{array}$ \\
\hline price (x5) & $\begin{array}{ll}\text { - } & \text { Reasonable prices of entry ticket } \\
\text { - } & \text { Cheap accommodation and catering facilities } \\
\text { - } & \text { Cheap entertainment or recreational facilities } \\
& \text { Provide local souvenirs that are worth the money }\end{array}$ \\
\hline
\end{tabular}

Tourists were asked to report their perceptions of those variables offered by Candirejo Tourism Village, on a scale of five choices (5 points Likert-type scale), from strongly disagree (1) to strongly agree (5). They were also asked to answer open-ended questionnaire that contains a set of questions about their profile, suggestions and recommendations. Besides, the author did a field observation and collected the data in a form of note about situation and case around the study's object. Secondary data were obtained from tracing documents and data sourced from tourism managers in Candirejo Village. This data supported the information 
of primary data which were got by doing the survey and direct field observation, such as number of tourists, profile of Candirejo Tourism Village and attractions list.

The daily number of tourists to Candirejo Tourism Village and their arrival times are uncertain. On the other hand, author should take data with certain practical criteria only at a limited time and at a shoestring budget. Therefore, author used accidental sampling as sampling technique. According to Premono and Kunarso (2008), respondents that taken through accidental sampling for this study are tourists who accidentally met at the time. This method can be a way to collect information from respondents who are easily accessible to the author. All questionnaire studies which depend upon the voluntary cooperation of people will be affected by accidental sampling. The willingness of respondents to participate will give high pertinent questionnaire reply (Etikan et al., 2016; McNemar, 1940)

The profile of respondents is the tourists who visited Candirejo Village and must age 17-60 years. The number of respondents taken was 36 people. The selection of these respondents was determined based on the consideration that they had fulfilled the minimum requirement for a large sample number $(n \geq 30)$, so that a sample data was assumed to have normal distribution to be processed statistically (Delice, 2008).

The data analyses were performed on SPSS 16.0. The methods adopted included descriptive statistics analysis and multiple regressions analysis, following Sarwono (2017). The distribution of basic attributes of the participants can be understand through descriptive statistics analysis. Before the questionnaire was distributed, the validity and reliability of the questionnaire were tested. The validity test used Pearson test, while the reliability test used Cronbach Alpha test. Validity and reliability tests were conducted to determine whether the questionnaire was consistent and stable. Lastly, multiple regression analysis was employed to investigate determinants, which affect the level of satisfaction of tourists in Candirejo Tourism Village. Multiple regressions is a statistical tool to determine how multiple independent variables (five factors) are related to a dependent variable (tourists satisfaction).

This research is explanatory in the form of causality between variables. In this study, the relationship between Job Skills based on local wisdom "Pageh, Puguh, lan Jengah, Job Achievement, and Employee Performance in LPDs in Buleleng Regency. Development of a model in this study attempts to predict the causality relationship between variables. This is to determine the effect of job skills based on local wisdom in the LPD. The research location was carried out at the Village Credit Institution (LPD) in Buleleng Regency. The sample used in this research was 60 LPDs out of 142 total populations spread across Buleleng Regency.

The research instrument used was a questionnaire as a data collection tool. Of the 60 questionnaires distributed, all questionnaires have been returned and filled out completely. The collected data were analyzed using variance-based (Structural Equation Modeling-SEM) or Component-based SEM, which is known as Partial Least Square (PLS) Visual version 3.0. 


\section{RESULTS AND DISCUSSION}

Candirejo has been established as a tourism village with ecotourism principles since 2003. The village tour itself was initiated in 1990s when several local guides and lodge owners started to bring their tourists to the village area (Fatimah, 2015). It makes Candirejo Village one of the pioneers of the tourism village development in Central Java province, even in Indonesia (Fatimah, 2018). The number of tourists is significantly rising from 2003 to 2013. However, after 2013, the numbers tend to be stable.

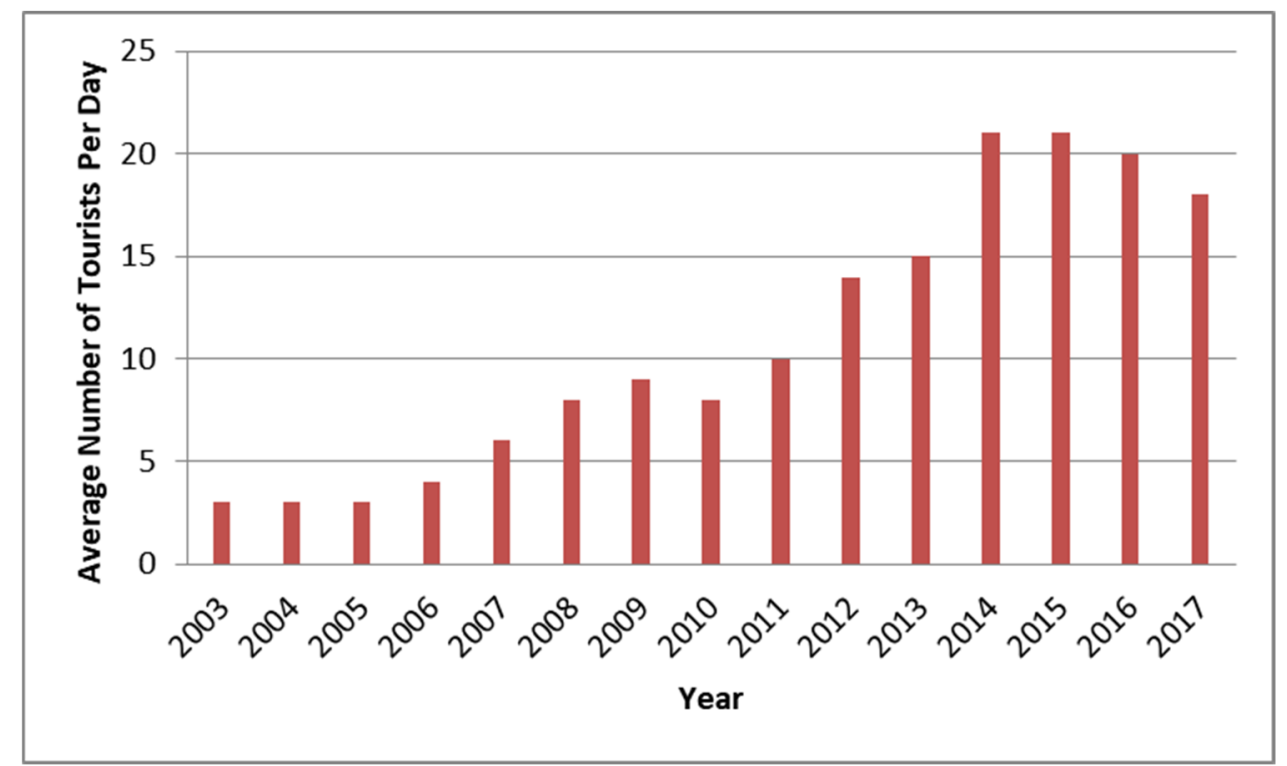

Figure 1. Average Number of Tourists Per Day (source: Candirejo Tourism Village Cooperative, 2018)

Data taken from respondents with different backgrounds are used to determine tourists' characteristics in Candirejo Tourism Village. Based on respondents, tourists are dominated by women (61.29\%). Most tourists are 31-37year-old $(32.26 \%)$ and the rest vary from 17-year-old to more than 51-year-old. Furthermore, most tourists work as employees (both public and private), with a percentage of $48.39 \%$, while the rest is diverse, such as students or college students, and other professions. The level of income of tourists is mostly less than one million rupiahs $(35.48 \%)$ and the rest varies from uncertain income (earned from nonpermanent job) to earn more than nine million rupiahs. The detailed composition of tourists in Candirejo Village can be seen in Figure 2. 

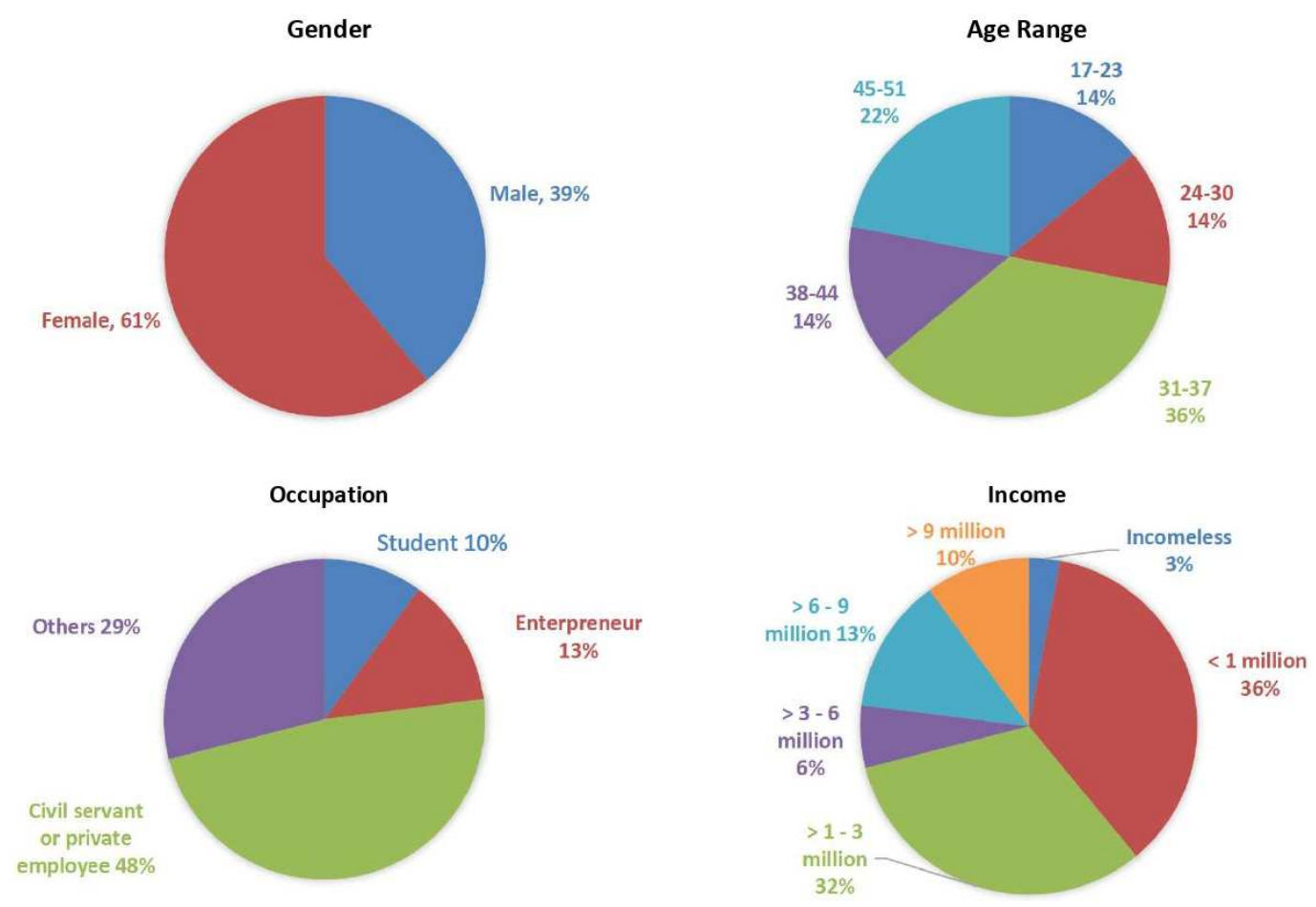

Figure 2. Profile of Tourists in Candirejo Tourism Village

From the income level above, which is shown in Figure 2, tourists can be classified into three economic classes: lower class, middle class and upper class. Asian Development Bank defines the lower class as adults whose monthly income is less than $\$ 60$. Middle class contains adults whose monthly income is about $\$ 60$ $\$ 600$. Upper class contains adults whose monthly income is more than $\$ 600$ (Nizar, 2015). Although the largest group comprises tourists who earn less than 1 million rupiahs per month $(36 \%)$, more than half of tourists $(51 \%)$ belong to the middle economic class. The economic classes of tourists are shown in Table 2.

Table 2. Distribution of tourists by economic class.

\begin{tabular}{lcc}
\hline Income (IDR) & Percentage & Economic Class \\
\hline Incomeless & $3 \%$ & lower \\
$<1$ million & $36 \%$ & \\
\hline$>1-3$ million & $32 \%$ & middle \\
$>3-6$ million & $6 \%$ & \\
$>6-9$ million & $13 \%$ & upper \\
\hline$>9$ million & $10 \%$ & \\
\hline
\end{tabular}

After the data from respondents were collected, the data were processed using multiple linear regression method in which the results can be seen in Table 3 below. The table below shows that the variation of tourists assessment on attraction, facility, service, accessibility, and price can explain tourists' satisfaction by $38.2 \%$. There are still other factors $(61.8 \%)$ outside this study that can explain tourists' satisfaction. Individually, only the price factor has a significant impact on the 
tourist's satisfaction of Candirejo Village. It is consistent with the composition of tourists who mostly earn less than one million rupiahs $(36 \%)$. These tourists will consider the price factor to visit a tourist attraction compared to other factors.

Table 3. Summary of multiple linear regression analysis.

\begin{tabular}{cccccc}
\hline Variable $\mathbf{x}$ & $\mathbf{t}$ & Sig. & F & Sig. & $\begin{array}{c}\text { Adjusted } \\
\text { R Square }\end{array}$ \\
\hline Attraction & 0.769 & 0.449 & 4.709 & $0.00363^{*}$ & $0.382^{*}$ \\
Facility & 0.479 & 0.636 & & & \\
Service & -0.086 & 0.932 & & & \\
Accessibility & 1.518 & 0.142 & & & \\
Price & 2.625 & 0.015 & & & \\
\hline
\end{tabular}

*Variable y: Tourists satisfaction

Furthermore, more than half of tourists $(51 \%)$ belong to the middle economic class. Tutek, Gebbie, Chan, and Durand (2015) stated that the middle class places importance on value for money. In order to spend their leisure time, they are more likely to choose budget travel. They want travel with a little sacrifice and get a lot of inventiveness and flexibility. Having a slice of the middle-class pie means businesses require innovation in offering value for money whilst still targeting specific needs. The challenge is adapting to (sudden) specific requirements once the tourist is at the destination, such as providing vegetarian food for vegetarian tourists.

The prices offered, pre-tour price, during tour and post-tour are, expected to be affordable and in accordance with the purchasing power of tourists, including tourists who have middle to lower economic levels. Candirejo Tourism Village's manager often offers special discounts for tourists who book in advance by email or phone. The fee for enjoying a package of tours around the village is 497,500 IDR. This price is relatively low since it includes daily meals (breakfast, lunch, and snacks) and accommodation. After joining a tour, tourists are also often offered additional tours or an extended stay at low prices.

Attraction, facility, service, accessibility and price factors jointly affect the tourists' satisfaction in Candirejo Village. This is because in discussing tourists' satisfaction, these factors cannot stand alone. Managers cannot develop one factor but ignore other factors. Meanwhile, the positive $F$ value indicates that the five factors studied directly affect tourists' satisfaction. The five factors are multi-factors which, if synergized optimally, can increase tourists satisfaction with Candirejo Village. Synergy can be done by developing tourist attractions, improving adequate facilities and accessibility, improving services and setting affordable prices for tourists.

Most tourists are office employees (48\%) and at 31-37-year-old (36\%). It becomes an indicator that Candirejo Tourism Village is a destination for relieving fatigue after a week of work since it has more nature-based scenery. In Candirejo Tourism Village, they could do fun things with their friends and families. What attracted them to Candirejo Tourism Village was not only the rural accommodation units but also the whole village nuance. They could have opportunities to come into contact with rural residents and see their daily life. It will integrate the rural 
accommodation experience within an intimistic that generates emotional experience. That is totally contrast with daily urban life.

In order to create a relaxing place, the manager prefers offering a package of tour around the village to offering certain attractions separately. This is in accordance with statement by Wilson et al. (2001): developing the package of attractions and businesses can attract and hold tourists, so tourists will stay longer. The tour package offered by Candirejo Tourism Village contains several attractions, including visit to the slondok household industry, making pottery, making woven art and playing gamelan. Tourists can also enjoy local custom attractions, local art attraction, also local home industries which sell local handicraft and souvenirs. Various attractions offered by Candirejo Tourism Village can be seen in Table 4. Rural livelihoods can be important learning environments (Kastenholz et al., 2017). The opportunity to explore the rural territories of Candirejo Tourism Village with the five senses; for example making rural crafts, seeing the production process of agricultural products, smelling characteristic odors, listening to characteristic sounds of the countryside; provides really meaningful knowledges to tourists. Kastenholz et al. (2017) added, educational experiences contribute to pleasant arousal.

Table 4. Available Attraction in Candirejo Tourism Village

\begin{tabular}{cc}
\hline Categories & Attraction Offered \\
\hline Nature & $\begin{array}{c}\text { Menoreh hill trekking, visiting Watu Kendil, Seeing in Progo } \\
\text { River, Walking around Tempuran Reservoir, Sunrise or } \\
\text { sunset experience in Dusun Butuh }\end{array}$
\end{tabular}

Cultural Javanese traditional ceremonies: nyadran, sedekah bumi, Jumat kliwon tradition; performing art: jathilan and kubrosiswo kethoprak, wayang kulit, topeng ireng or dayakan, gatoloco, sholawatan, rebana, karawitan

Education and Traditional cooking lesson, culinary, making pottery, making training woven art, playing traditional music (gamelan)

Agricultural Farming activities: paddy and cassava planting, harvesting, making slondok and another snacks from cassava

Live in Stay at local guest house, Walking around village, Horse cart tour, cycling around village

The most favorite thing of Candirejo Tourism Village is its nature. It is because its nature can make tourists feel fresh. There are several natural attractions that offered by Candirejo village, as listed in Table 4. Among those natural attractions, the most favorite attractions is the clean river. This may be because it is difficult to find a river with clear water. Tourists who come in Candirejo Tourism Village are usually invited to visit the river, then have free time without any interesting outdoor activities. The current river tour is expected to be combined with additional man-made tourism products such as river rafting with rubber boats, outbound or wooden bridges connecting the river banks. 
Furthermore, tourists also want the swimming pool to be blended with nature. The water of the pool can be flowed directly from the mountain which is close to Candirejo Village. According to Jotisalikorn and Zabihi (2005), infinity pool can be made to complete a tourism site highlighting nature. This pool is an amazing additional element in the midst of nature tourism. In 2016, Howie stated that infinity pool deliberately made with vague boundaries that makes tourists really feel united with nature. Tourists will get a more relaxed sensation than when tourists are in an ordinary swimming pool. Well balanced combination of natural and manmade attractions is frequently identified as a motivation for seeking the countryside (Kastenholz et al., 2017).

As a tourism destination highlighting the natural nuances of the countryside and the activities of its people, Candirejo Village also presents local art attractions. Traditional musical instrument, gamelan, which is the main entertainment of the community, is presented to tourists. Regrettably, tourists are immediately invited to play Javanese songs with gamelan without being given introductory activities to introduce the gamelan. For long duration, the gamelan game will be monotonous. Innovation and variation are needed in inviting tourists to play gamelan, such as ice breaker games for introducing gamelan and relieving boredom during playing gamelan.

Candirejo Village is rich in cultural arts. In addition to gamelan, Candirejo Village also has kethoprak, wayang kulit, jathilan, kubrosiswo, topeng ireng or dayakan, gatoloco, sholawatan, rebana, and other cultural arts. The rich cultural heritage of Candirejo Village is very interesting for tourists to visit. Unfortunately, if tourists want to watch this art, they have to order those art performances in advance. Therefore, tourists who come spontaneously without reservation cannot enjoy these cultural arts.

On the other hand, tourists want a cultural arts performance that can be seen while visiting, instead of just playing gamelan. It will be great if tourists are welcomed with unique traditional music and dance (such as jathilan and gamelan) by residents. According to OECD (2009), local cultural performances drive regional attractiveness and competitiveness since many tourists are in search of atmosphere and difference. This welcoming performance might be a source of identity and differentiation of Candirejo Tourism Village that other places do not offer. Their own style of welcoming performance is also a kind of friendly service (Suanmali, 2014). It affects tourists impressions. It is closely linked to word-ofmouth recommendations, one of the most valuable sources of travel information (Wilson et al., 2001).

Tourists are delighted when they are involved in the performing arts with local community, to dance and sing along Javanese songs. Moreover, it will be a pleasure if they can also wear costumes of art performances worn by the villagers of Candirejo. Blending with local cultural arts is expressed as a different thing to be fun when travelling in Candirejo Tourism Village. Wilson et al. (2001) and also Blesic, Pivac, Dordevic, Stamenkovic, and Janicevic (2014) stated that special cultural events play a significant role in rural tourism because those art attractions not only have drawn tourists to the area but have helped promote local tourism as a package. They can enhance the tourist image of local communities and their social cohesion. 
In terms of facilities, the physical facilities which are needed by tourists are resorts, public toilets and places to eat. Actually, at this time, Candirejo Village has offered guest houses to tourists who want to feel the natural nuance of the countryside for longer. Guesthouses are residents' homes specially prepared for tourists. Unfortunately, these guest houses are too modern so that they lose their rural characteristics. The floor was tiled, the walls were made of concrete, the mattress was a spring bed, the toilet used toilet seat, and some houses used air conditioning.

On the other hand, residents' homes that are not used as guest house, still look traditional. Those homes are mostly using earthen floor, even some of them are using bamboo woven panels for the walls. This traditional uniqueness sometimes becomes a thing that tourists look for, and should be used as a guest house. However, this uniqueness is not balanced with good cleanliness and neatness. They seemed perfunctory and less beautiful. If one day the management wants to use those traditional houses as guest houses, the management should involve architectural experts. This means it is expected to fix the layout, so the sale value of guest houses to tourists can increase.

The existence of Candirejo Village as a tourist village has not been supported by the availability of adequate public facilities, such as toilets and places to have food and beverages. Public toilets are still a few and in dirty conditions. Most tourists, mostly women $(61,29 \%)$, want the management to increase the number of safe and clean toilets. It means they need female-friendly public toilets, which are: be in a safe location; have a clearly marked female toilet section with a separate entrance; have good lighting; have robust private cubicles; provide clean water; and cater for menstrual and other hygiene requirements. Candirejo Village also has not yet provided a place to eat. Actually, the management has prepared snacks or meals in the taste of Central Java, but it should be ordered in advance. It is something that some tourists do not like. They want a food court or cafe as an addition to the dining choices, which are available without prior reservation. This dining place can be used as a means of relaxing after a day of exploring the village or as a culinary tour.

About the accessibility, in Candirejo Tourism Village, most of the streets are paved and flat roads. It supports travelling and daily activities of the people. Tourists can enjoy a tour by a horse cart tour. However, accessibility and convenience are not fully optimal in encouraging tourist visits. There is no public transportation that actually reaches directly to Candirejo Tourism Village. Tourists still have to charter a car to get to the location. Collaboration with Borobudur Temple tourism managers is required to take advantage of tourist arrivals at Borobudur Temple, so they can also visit Candirejo Tourism Village. The existence of a tour package for Borobudur Temple area can be an advantage for Candirejo Tourism Village. It can ease tourists to access Candirejo Tourism Village because it is an integrated tour package with Borobudur temple. Tourists can choose to enjoy Borobudur temple in the afternoon or evening, then sleep at a guest house in Candirejo Tourism Village.

\section{CONCLUSION}

The importance of tourist satisfaction makes it necessary to measure tourist's satisfaction and the factors affecting it. Measurement of satisfaction helps the 
manager understand visitors' motivations and behaviours and use it to increase tourism performance. Individually, only the price factor has a significant effect on the tourists' satisfaction of Candirejo Tourism Village. Attractions, facilities, services, accessibility, and prices jointly affect the tourists' satisfaction in Candirejo Tourism Village. In discussing tourist satisfaction, the five factors cannot stand alone. Managers cannot develop one factor but ignore other factors. The five factors studied directly affect tourists' satisfaction. Attractions, facilities, services, accessibility and prices are multi-factors. If these factors synergize optimally, tourists satisfaction with Candirejo Tourism Village will increase.

The rising of the middle class affects the profile of tourists in Candirejo Tourism Village. Therefore, the manager should work to get businesses and attractions that would attract middle class individuals. They require innovation in offering value for money whilst still targeting specific needs. Great value for money means a little sacrifice and get a lot of inventiveness and flexibility, including pleasant attractions. A combination of both nature and man-made elements as a unity is expected to attract tourists. It will be great if the manager can provide interesting activities at the river and build the scenic infinity pool that makes tourists really feel united with nature.

The special cultural events also play a significant role in attracting tourists. Their cultural performance might be a source of identity and differentiation of Candirejo Tourism Village that other places do not offer. The art attractions not only have drawn tourists to Candirejo Tourism Village but have helped promote local tourism as a package. Their hospitality should be improved to gain a friendlyservice impression, for example: welcoming tourists with unique traditional music and dance.

In terms of facilities, the physical facilities which are primary needed by tourists are public toilets and places to eat. Most women need female-friendly public toilets. A food court or cafe is needed as an addition to the dining choices, which are available without prior reservation. This dining place can be used as a means of relaxing after a day of exploring the village or as a culinary tour. For accommodation, a homestay program is a recommended option in rural tourism. The management should keep their old traditional houses to remain its originality without any transformation, and give more attention to the cleanliness and neatness. The architectural experts should be involved to fix the layout. For high standards, resorts operated by the locals would be another option.

Stakeholders collaboration will give advantages to Candirejo Tourism Village improvement. Government participation is needed in providing touristfriendly public transportation that actually reaches directly to Candirejo Tourism Village. Another thing that can be done to improve accessibility is making an integrated tour package with Borobudur temple. Finally, the right mix of businesses for tourism is a major factor for successful rural tourism development in Candirejo Tourist Village; including affordable price, friendly service, adequate accessibility and facility, and a package of attractions that entice tourists to stay and spend money locally. 


\section{ACKNOWLEDGMENT}

The author would like to shows gratitude to all parties who supported and helped during the research: Agus Setiadi, S.Pt., M.Sc., Ph.D. (Lecturer at Faculty of Animal and Agricultural Science, Diponegoro University), Citizens of RT 06 RW 06 Kalicari, Candirejo Village communities and Candirejo Tourism Village Cooperative staffs.

\section{REFERENCES}

Akama, J. S., \& Kieti, D. M. (2003). Measuring Tourist Satisfaction with Kenya's Wildlife Safari: a Case Study of Tsavo West National Park. Tourism Management, 24, 73-81.

Blesic, I., Pivac, T., Dordevic, J., Stamenkovic, I., \& Janicevic, S. (2014). Cultural Events as Part of Cultural Tourism Development. Case Study: Sombor and Apatin (Serbia). Acta Geographica Slovenica, 54(2), 381-390. https://doi.org/10.3986/AGS54406

Candirejo Tourism Village Cooperative. (2018). Annual Report 2018.

Damanik, J., Cemporaningsih, E., Marpaung, F., Raharjana, D. T., Rindrasih, E., Brahmantya, H., \& Wijaya. (2018). Membangun Pariwisata dari Bawah: Catatan Penelitian terhadap Desa Wisata Penerima Program PNPM Pariwisata. Gadjah Mada University Press.

Delice, A. (2008). The Sampling Issues in Quantitative Research Educational Sciences. Theory \& Practice, 10(4).

Etikan, I., Musa, S. A., \& Alkassim, R. S. (2016). Comparison of Convenience Sampling and Purposive Sampling. American Journal of Theoretical and Applied Statistic, 5(1), 1-4. https://doi.org/10.11648/j.ajtas.20160501.11

Fatimah, T. (2015). The Impacts of Rural Tourism Initiatives on Cultural Landscape Sustainability in Borobudur Area. Procedia Environmental Sciences, 28, 567577. https://doi.org/10.1016/j.proenv.2015.07.067

Fatimah, T. (2018). Community-Based Spatial Arrangement for Sustainable Village Environmental Improvement - Case Study of Candirejo Village, Borobudur, Indonesia. Energy Procedia, 153, 389-395. https://doi.org/10.1016/j.egypro.2018.10.074

Gokovali, U., \& Bahar, O. (2006). Contribution of Tourism to Economic Growth: a Panel Data Approach. Anatolia, 17(2), 2-5. https://doi.org/10.1080/13032917.2006.9687184

Handriana, E. (2015). Menggugah Desa Wisata Jawa Tengah. Suara Merdeka. http://berita.suaramerdeka.com/menggugah-desa-wisata-jawa-tengah/

Hayati, N., \& Novitasari, D. (2017). An Analysis of Tourism Service Quality Toward Customer Satisfaction (Study on Tourists in Indonesia Travel Destinations to Bali). International Journal of Marketing and Human Resource Management, 8(2), 9-20.

Jotisalikorn, C., \& Zabihi, K. (2005). Contemporary Asian Pools and Gardens. Periplus Editions.

Kastenholz, E., Carneiro, M. J., Marques, C. P., \& Loureiro, S. M. C. (2017). The Dimensions of Rural Tourism Experience: Impacts on Arousal, Memory, and Satisfaction. Journal of Travel and Tourism Marketing, 35(2), 189-201. https://doi.org/10.1080/10548408.2017.1350617 
Kementerian Perdagangan Republik Indonesia. (2011). Warta Ekspor. Kementerian Perdagangan Republik Indonesia.

Kerdpitak, C., \& Heuer, K. (2016). Key Success Factors of Tourist Satisfaction in Tourism Services Provider. The Journal of Applied Business Research, 32(4), 1237-1242.

Kurniasih, D. M., Nihayah, S. A., Sudibyo, \& Winda, F. N. (2017). Tourism Village Model Based on Local Indigenous: Case Study of Nongkosawit Tourism Village, Gunungpati, Semarang. E3S Web of Conferences, 31(09011), 1-6. https://doi.org/10.1051/e3sconf/20183109011

McNemar, Q. (1940). Sampling in Psychological Research. Psychological Bulletin, 37(6), 331-365. https://doi.org/10.1037/h0063476

Permanasari, I. K. (2011). Pemberdayaan Masyarakat Melalui Desa Wisata dalam Usaha Peningkatan Kesejahteraan Desa Candirejo, Magelang, Jawa Tengah. Universitas Indonesia.

Sadeh, E., Asgari, F., Mousavi, L., \& Sadeh, S. (2012). Factors Affecting Tourist Satisfaction and Its Consequences. Journal Of Basic And Applied Scientific Research, 2(2), 1557-1560.

Santosa, \& Saputra, A. D. (2018). Identifikasi Daya Tarik dan Implementasi Bauran Pemasaran Konsep 7P Desa Wisata Candirejo Saat Low Season. Jurnal Nusantara, 1(1), 41-48.

Sarwono, J. (2017). Mengenal Prosedur-Prosedur Populer Dalam SPSS 23. Elex Media Komputindo.

Shahrivar, R. B. (2012). Factors That Influence Tourist Satisfaction. Journal of Travel and Tourism Research, Special Issue Destination Management, 62-79.

Stevianus. (2014). Pengaruh Atraksi Wisata, Fasilitas dan Kualitas Pelayanan terhadap Kepuasan Pengunjung di Taman Margasatwa Ragunan Jakarta. Jurnal Ekonomi Bisnis, 19(3), 39-44.

Suanmali, S. (2014). Factors Affecting Tourist Satisfaction: an Empirical Study in The Northern Part of Thailand. SHS Web of Conferences, 12(01027), 1-9. https://doi.org/10.1051/shsconf/20141201027

Sulistyadi, Y., Eddyono, F., \& Entas, D. (2019). Pariwisata Berkelanjutan Dalam Perspektif Pariwisata Budaya di Taman Hutan Raya Banten. Uwais Inspirasi Indonesia.

Tutek, E., Gebbie, M., Chan, K. Y. G., \& Durand, S. (2015). Tourism Megatrends: 10 Things You Need to Know About The Future of Tourism. Horwath HTL.

Wilson, S., Fesenmaier, D. R., Fesenmaier, J., \& Van Es, J. C. (2001). Factors for Success in Rural Tourism Development. Journal of Travel Research, 40, 132138. https://doi.org/10.1177/004728750104000203

Yusendra, M. A. E., \& Paramitasari, N. (2018). Identifying Factors Affecting Domestic Tourist Satisfaction on Tourist Destinations in Indonesia. DeReMa Jurnal Manajemen, 13(2), 157-174. https://doi.org/10.19166/derema.v13i2.792 